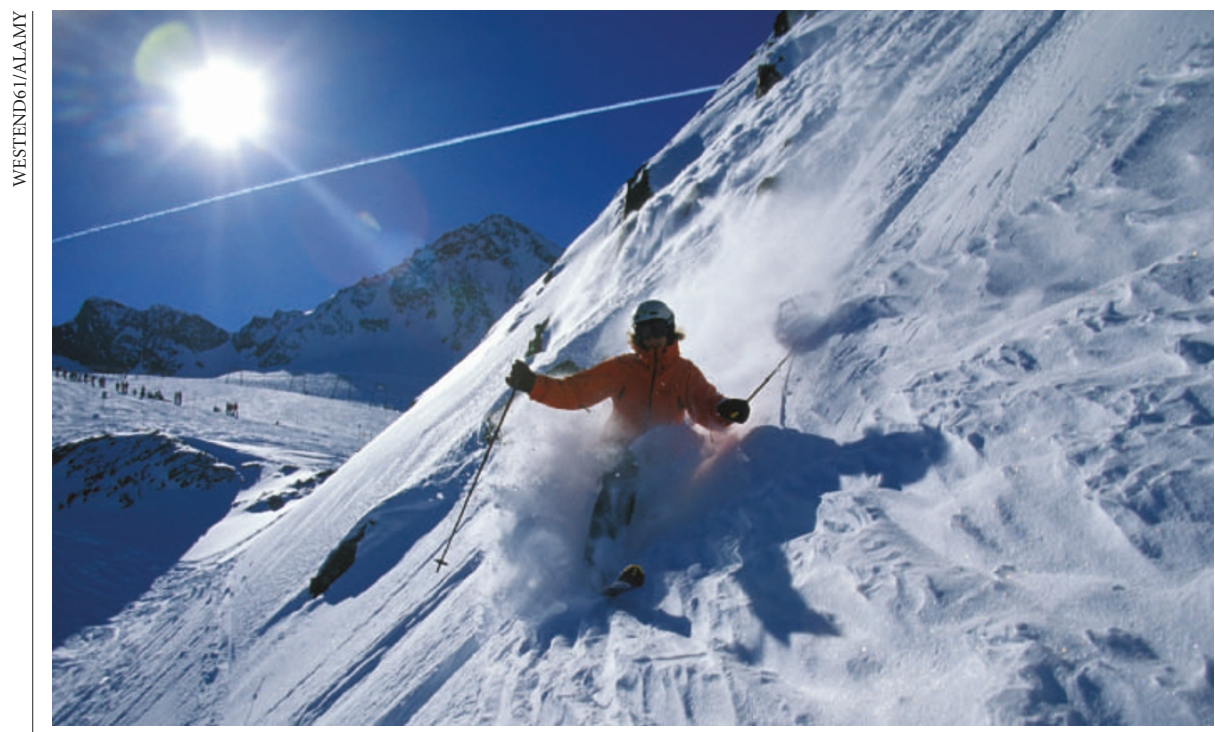

Slippery slope: climate change is driving ski resorts to head for higher altitudes in search of snow.

\section{Ecologists mount protest over lofty plans for Alpine ski runs}

Quirin Schiermeier, Munich

As summer comes to a close and millions of skiers eagerly prepare for winter, a heated argument has broken out over plans to build new ski resorts high in the Alps.

The disagreement has been sparked by an initiative to open the second largest glacier in the eastern Alps - the pristine Gepatsch glacier in Tyrol, Austria - to skiers.

Climate change is causing snow lines to creep farther up many mountains, leaving some small ski resorts with access to snow for only a very short time. In response, many ski centres are looking to expand into glacial areas at higher altitudes.

But ski-lift stations, restaurants and piste vehicles produce tonnes of harmful waste, grease, lubricant oils and salts, says Peter Hasslacher, a development planner and conservation expert with the Austrian Alpine Club in Innsbruck. When placed on glaciers, such facilities soon pollute the surrounding soil and water.

Nevertheless, a recent change in Tyrol's environmental law permits the construction of ski lifts in high regions - even in areas that form part of a European network of protected natural landscapes.

Environmentalists have expressed horror at the Gepatsch expansion plan, which they say could ruin one of Europe's last wildernesses. If it goes through, they say, it will open the floodgates for similar projects in other parts of the Alps. "Driving skiers higher and higher is the worst strategy if you want ecologically sound winter tourism," Hasslacher says.

But the tourist industry is facing a difficult future. According to a recent study by the
United Nations Environment Programme, about half of Switzerland's skiing resorts are likely to suffer from a lack of snow in the near future. Within a few decades, the losses to Swiss tourism could reach US $\$ 1.6$ billion per year, says the UN report Climate Change and Winter Sports: Environmental and Economic Threats.

Leisure companies, such as the French market leader Compagnie des Alpes, are already focusing investment on high Alpine regions, says Michel Revaz of the International Commission for the Protection of the Alps (CIPRA), a non-governmental conservation group based in Liechtenstein. Huge skiing areas, such as those around Zermatt and Saas Fee in Switzerland, are promising a good return on capital, he says.

Environmentalists agree that Alpine communities need to find a way to address their potential losses from climate change. But they would rather they market forms of tourism that have less of an effect on wilderness areas — such as developing conference facilities, or providing support for hiking or sledding in patchy areas of snow at lower altitudes.

"High-altitude skiing is a ruinous waste of energy and natural resources," says Andreas Götz, CIPRA’s director. "Clinging to it shows a lack of imagination, and sets a bad example for emerging skiing tourism in places such as China and Russia."

The Alpine Convention, an agreement signed by Austria, Slovenia, Italy, Switzerland, Liechtenstein, Germany and France, does not expressly disallow new high-altitude ski areas. But ministers of the seven countries bordering on the Alps will discuss possible changes to these regulations at a meeting in Bavaria in November.

\section{Burnt books get cold shoulder in restoration effort}

Karoline Schwarzberg, Munich

Life in the freezer is about to become a reality for thousands of ancient books in eastern Germany.

The books form part of the Duchess Anna Amalia Library in Weimar, one of Europe's most valuable collections, which was badly damaged by fire on 2 September.

Some 30,000 of the million volumes in the library's collection were destroyed in the blaze. And at least 40,000 burnt and water-logged books and manuscripts now need to be restored.

The damaged books are being taken to the Centre for Book Conservation in Leipzig, where they will be stored below $-22{ }^{\circ} \mathrm{C}$ to keep mould and bacteria at bay. They will then be freeze-dried before restoration begins. The federal government has pledged $€ 4$ million (US\$5 million) to kick-start the effort, and private donations are already coming in to help complete it.

"Fortunately, the books were packed

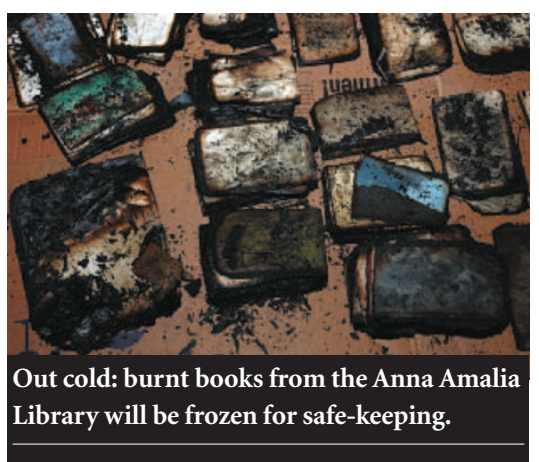

very close together, so the main damage has been to the edges of the pages and on the book covers," says Robert Fuchs, a conservator at the University of Applied Sciences in Cologne.

"The fire was a tragedy for the world of German literature," says Martin Strebel, a restorer who works for the Abbey Library in St Gallen, Switzerland. But he adds that many tools are available to repair the damaged books.

Burnt page edges can be replaced with new paper, for example. And if whole pages look set to crumble, the two sides can be separated and stabilized by a sheet of paper placed in the middle. But only a few experts can carry out this procedure, which is expensive and time-consuming.

Weimar was home to some of Germany's most famous writers, including Nietzsche and Goethe. The library, created in 1761 , is listed as a World Heritage Site. 